\title{
Biofiltration, growth and body composition of oyster Crassostrea rhizophorae in effluents from shrimp Litopenaeus vannamei ${ }^{1}$
}

\author{
Biofiltração, crescimento e composição corporal da ostra Crassostrea rhizophorae \\ em efluentes do camarão Litopenaeus vannamei
}

\author{
Rafael Vieira de Azevedo², William Cristiane Telles Tonini², Marcel José Martins dos Santos ${ }^{2}$ e Luís Gustavo \\ Tavares Braga*
}

\begin{abstract}
The objective of this study was to use oyster as biofilter to improve the quality of effluent from shrimp farming and to assess its growth performance and body composition. It was distributed 1,080 oysters into lanterns in fiberglass tanks $(170 \mathrm{~L})$ in a completely randomized design with three treatments $(0,60$ and 120 oysters $)$ and six replicates. It was used the effluent from the sedimentation tank. It was measured weekly: temperature, salinity, dissolved oxygen and $\mathrm{pH}$, and it was analyzed ammonia-N, nitrite-N, nitrate-N, orthophosphate-P, suspended solids and chlorophyll- $a$ of the input effluent. The control tanks (without oysters) were more efficient at removing ammonia-N, nitrite- N, nitrate-N and orthophosphate-P. The tanks containing oysters were more efficient at removing suspended solids and chlorophyll- $a$. Stocking density influenced the height growth of oysters, but not width. Wet and daily weight, condition and yield index were not affected by stocking density, and a significant increase in comparison to the initials values was observed. Body composition was not affected by stocking density, and a significant difference $(p<0.05)$ in relation to the initial composition of ether extract was observed. For the other fractions, there was no significant difference $(p>0.05)$. Under the conditions evaluated, the oyster Crassostrea rhizophorae improves water quality and presents growth rates and body composition similar to those obtained in traditional crops.
\end{abstract}

Key words: Aquaculture. Integrated system. Performance.

RESUMO - Objetivou-se utilizar ostras como biofiltros na melhoria da qualidade dos efluentes da carcinicultura e avaliar seu desempenho zootécnico e composição corporal. 1.080 ostras foram distribuídas em lanternas em 16 tanques de fibra de vidro $(170$ L), em um delineamento inteiramente casualizado, com três tratamentos (0; 60 e 120 ostras) e seis repetições. Utilizouse o efluente proveniente do tanque de sedimentação. Semanalmente foram medidos: temperatura, salinidade, oxigênio dissolvido e pH, e analisados amônia, nitrito, nitrato, fosfato, total de sólidos suspensos e clorofila- $a$ do efluente de entrada. Os tanques controle foram mais eficientes na remoção de amônia, nitrito, nitrato e fosfato. Os tanques contendo ostras foram mais eficientes na remoção de total de sólidos suspensos e clorofila- $a$. A densidade de estocagem influenciou o crescimento em altura das ostras, porém não em largura. O peso úmido e o diário, índice de condição e rendimento não foram influenciados pela densidade de estocagem, observando-se aumento significativo em relação aos valores iniciais. A composição corporal não foi influenciada pela densidade de estocagem, observando-se diferença significativa $(p<0,05)$ em relação à composição inicial em extrato etéreo. Para as demais frações não houve diferença significativa $(p>0,05)$. $C$. rhizophorae melhora a qualidade da água, além de apresentar bons índices de desempenho e composição corporal.

Palavras-chave: Aquicultura. Sistema integrado. Desempenho zootécnico.

\footnotetext{
*Autor para correspondência

${ }^{1}$ Recebido para publicação em 10/12/2013; aprovado em 03/09/2014

Parte da Dissertação de Mestrado do primeiro autor apresentada na Universidade Estadual de Santa Cruz/UESC

${ }^{2}$ Universidade Estadual de Santa Cruz/UESC, Ilhéus-BA, Brasil, azevedorv84@gmail.com, willcttonini@gmail.com, marcel_martins_santos@ hotmail.com

${ }^{3}$ Departamento de Ciências Agrárias e Ambientais, Nutrição de Organismos Aquáticos, Universidade Estadual de Santa Cruz/UESC, Campus Soane Nazaré de Andrade, Rodovia Jorge Amado, km 16, Salobrinho, Ilhéus-BA, Brasil, 45.662-900, 1gtbraga@gmail.com
} 


\section{INTRODUCTION}

The reduction of natural fish stocks is a problem related to social welfare and global food security (JIANG, 2010). One of the most promising alternatives for the supply of high nutritional value food is aquaculture, mainly due to the increasing deficit between the amount of fish caught and consumer demand (CAMARGO; POUEY, 2005).

Among the aquatic species produced worldwide, the cultivation of shrimp Litopenaeus vannamei, accounted for $15.4 \%$ of total income from aquaculture (FOOD AND AGRICULTURE ORGANIZATION OF THE UNITED NATIONS, 2009). In Brazil, despite the difficulties that the segment have been presenting in recent years, the production of $L$. vannamei remained at a level of 70 thousand tons in 2009 (ROCHA, 2011). In 2010, marine aquaculture contributed $17.7 \%$ of national aquaculture production corresponding to $69,422 \mathrm{t}$, with $97 \%$ of this production originating from shrimp farm (MINISTÉRIO DA PESCA E AQUICULTURA, 2012).

The emission of effluents from the farms of shrimp cultivation, if not treated before discard in the receiver water body, represents one of the greatest impacts generated by the activity. The use of sedimentation tanks in shrimp-producing countries has been a way of treating the effluents. These tanks are effective in reducing the discharge of suspended particles, but they are not effective in reducing concentrations of dissolved nutrients (JACKSON et al., 2003).

Thus, according to Jones, Dennison and Perston (2001), the integration of other assimilatory organisms (bivalve mollusc and macroalgae), increases sedimentation efficiency in reducing solid particles and nutrients dissolved in effluent. Bivalve molluscs have been studied as part of integrated aquaculture, improving water quality and also acting as an economic complement (LEFEBVRE; BARILLÉ; CLERC, 2000). However, most studies are carried out in laboratories under controlled conditions.

The objective of this study was to evaluate the use of the oyster Crassostrea rhizophorae as biofilter and to evaluate its animal performance and body composition by using the effluents from the cultivation of shrimp Litopenaeus vannamei.

\section{MATERIAL AND METHODS}

The study was conducted for six weeks, in a farm cultivation of marine shrimp in the municipality of

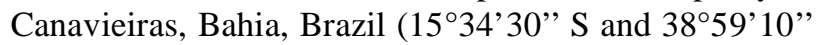
W). The farm has seven digged ponds, with three acres of water surface and a sedimentation tank, with $500 \mathrm{~m}^{2}$ and $2 \mathrm{~m}$ depth. It was cultivated in the ponds the shrimp
Litopenaeus vannamei, with 30 days of cultivation at the beginning of the experiment, at a density of 10 individuals per $\mathrm{m}^{2}$, fed twice daily with commercial pellet feed containing $36 \%$ crude protein, $7 \%$ ether extract, $9 \%$ fiber and $12 \%$ mineral matter (guarantee levels provided by the manufacturer).

The experimental structure consisted of 18 fiberglass tanks, with cylindrical shape, with a capacity of $170 \mathrm{~L}$ of useful volume, installed about five meters from the sedimentation tank. By using a 1-HP water pump, the effluent from the shrimp cultivation ponds was pumped from the first third (in relation to the extension) of the sedimentation tank and distributed in the experimental system independently through PVC tubing, with the entry and exit through the surface and exit through the bottom of each tank. The distribution was made in a discontinuous way, with a sixhour interval between pumping and rest of the effluent in experimental tanks, controlled by a timer (Figure 1).

A plot of 1,500 oysters (Crassostrea rhizophorae) was obtained from a commercial production in Baía de Camamu, Bahia, Brazil (1340'02" $\mathrm{S}$ and $38^{\circ} 55^{\prime} 08^{\prime}$ " W). It was selected 1,080 oysters $(46.31 \pm 1.27 \mathrm{~mm})$, which were distributed in cultivation lanterns with three shelves (floors) (Figure 1), with cylindrical shape $(0.30 \mathrm{~m}$ diameter, $1.20 \mathrm{~m}$ wide and $15 \mathrm{~mm}$ mesh between knots), according to treatment: 0 oyster (control, only lanterns), 60 oysters (20 per floor) and 120 oysters (40 per floor). Each lantern was then allocated in an experimental tank. The experiment was a completely randomized design with three treatments and six replications.

The physical, chemical and biological variables of effluent of experimental tanks were analyzed weekly. It was analyzed in situ: dissolved oxygen using an oxygen meter (YSI model 55-12FT, YSI Corporation, Owings Mills, MA, USA), $\mathrm{pH}$ and temperature by using a multiparameter (YSY model 63-10FT, YSI Corporation, Owings Mills, MA, USA), and salinity by an optical manual refractometer (Atago S/Mill-E, Atago Co. Ltd., Tokio, Japan). To perform the biological analysis, two liters of input and exit effluent of each experimental tank were collected weekly and placed and kept refrigerated in isothermal box with ice and shipped to Universidade Estadual de Santa Cruz (UESC), Ilhéus, Bahia, Brazil. The analysis of chlorophyll- $a$ was determined by filtering a given volume of effluent in Whatman GF/F filters, which were immediately frozen. Extraction in acetone and calculation of the concentration of chlorophyll- $a$ were carried out according to Jeffrey and Humphrey (1975).

To determine the concentrations of suspended solids, a known volume of effluent was filtered in a predried and pre-weighed Whatman GF/C glass fiber filter $\left(110^{\circ} \mathrm{C}, 24 \mathrm{~h}\right)$. The filter was then dried at $60{ }^{\circ} \mathrm{C}$ for $24 \mathrm{~h}$ 
Figure 1 - Schematic representation of the experimental system and details of the structure of the cultivation of oyster. Arrows indicate effluent flows, $\mathrm{T}$ = fiberglass tank, $\mathrm{L}=$ lantern with three "floors"

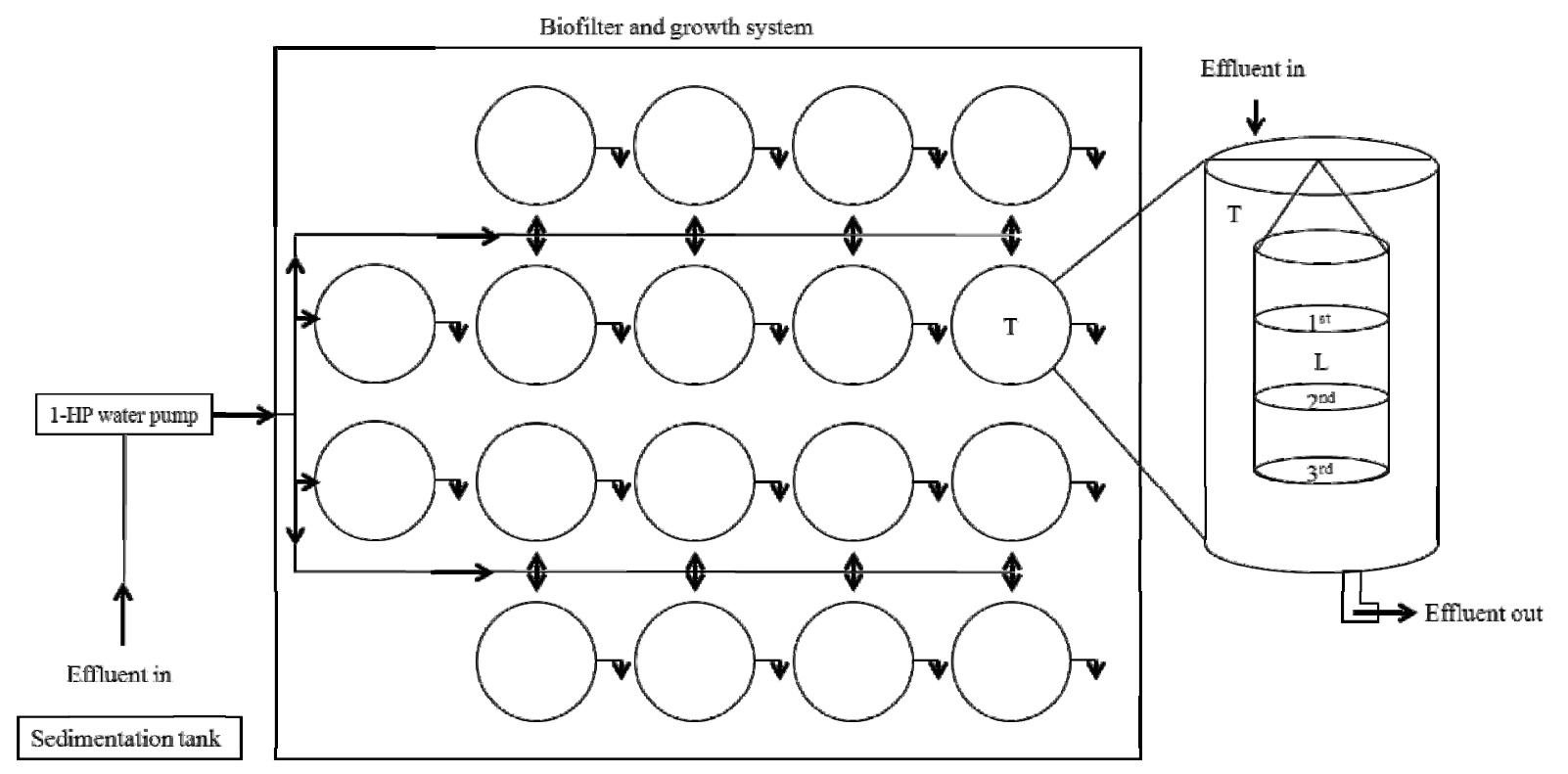

and the concentration of suspended solids was calculated as the difference between the initial and final weight.

The analysis of ammonia-N (un-ionized plus ionized ammonia as nitrogen), nitrite- $\mathrm{N}$ (nitrite as nitrogen), nitrate- $\mathrm{N}$ (nitrate as nitrogen) and orthophosphate-P were analyzed by a spectrophotometer (Hanna HI 83203, Hanna Instruments Inc., Woonsocket, Rhode Island, USA), by using methods, respectively, Nessler, ferrous sulphate, cadmium reduction and amino acid.

Removal of ammonia-N, nitrite- $\mathrm{N}$, nitrate-N, orthophosphate-P, suspended solids and chlorophyll- $a$ [(concentration in the input effluent - concentration in the effluent after the experimental tanks) / concentration in the input effluent] $\times 100$ was calculated for each treatment weekly.

In the first and last days of the experiment, all oysters were measured for height and width with a $0.01-\mathrm{mm}$ precision manual caliper. The height is defined as the maximum distance between the umbo and the ventral part of the shell width and the distance between the right and left valves.

Ten oysters at the beginning of the experiment and 10 oysters per replicate at the end of experiment was separated and shipped under refrigeration to the Laboratório de Nutrição e Alimentação de Peixes (Aquanut) at UESC. The oysters were rinsed with fresh water and brush cleaned to remove the debris and for subsequent analysis.

The animals were weighed to obtain the gross weight and by using a short-bladed knife, the soft parts of the valves were split off which were weighed separately. The soft parts were taken to an oven $\left(80^{\circ} \mathrm{C}\right)$ for $24 \mathrm{~h}$ for dry weight determination. For the weighing, it was used a 0.01-g accuracy electronic scale.

To evaluate the performance of the oysters, the analyzed variables were: daily growth [(final height or width - original width or height) / experimental period], condition index [(soft tissue dry weight / weight of the valves $) \times 100$ ], yield [(wet weight $/$ weight $) \times 100$ ], daily weight gain [(final wet or dry weight - initial wet or dry weight $/$ experimental period $) \times 1000$ ] and survival [(dead individuals / living individuals $) \times 100$ ].

For body condition analysis, five oysters (soft parts) per replicate were mixed and ground for determination of contents of moisture, crude protein, ether extract and ash (DETMANN et al., 2012).

Data on nutrient removal, animal performance and body composition obtained at the end of the experiment were submitted to ANOVA at $5 \%$ of significance level. In case of differences, it was applied the Tukey's HSD test by using the software Statistical Analysis System 9.0 (SAS Inc., Cary, NC, USA).

\section{RESULTS AND DISCUSSION}

During the experimental period, the temperature of effluent entering into the system ranged from 26.5 to $30.3{ }^{\circ} \mathrm{C}$ with extremes in the first and fifth weeks. 
Dissolved oxygen presented minimum and maximum values from 3.50 to $4.81 \mathrm{mg} \mathrm{L}^{-1}$, respectively. Salinity ranged from 11 to $16 \mathrm{~g} \mathrm{~L}^{-1}$, with a minimum value in the first two weeks and a maximum value in the last two weeks. The $\mathrm{pH}$ ranged from 7.24 in the first week to 8.11 in the sixth week, with maximum observed in the fifth week (Figure 2).

Environmental conditions directly influence the filtration rate of bivalves (JONES; PERSTON; DENNISON, 2002) and consequently growth, meat quality and survival of oysters. The physical and chemical variables of the input effluent, during the experimental period, except for salinity, remained within the range suitable for cultivation of Crassostrea rhizophorae (GUIMARÃES et al., 2008; MADRIGAL et al., 1985; REYES, 1995). However, according to Madrigal et al. (1985), the optimal filtration rate for C. rhizophorae is obtained at $28^{\circ} \mathrm{C}$ and salinity of $25 \mathrm{~g} \mathrm{~L}^{-1}$. Thus, although within the range tolerated by the species (GUIMAR ÃES et al., 2008), salinity during the experimental period is presented below ideal for filtration rate.
The results obtained for the removal of ammonia$\mathrm{N}$ from the effluent show that the control tanks reduced more efficiently $(p<0.05)$ the contents of levels of ammonia-N in relation to treatment with 60 and 120 oysters, and these were similar to each other $(p>0.05)$ (Figures 3 and 4).

Similar pattern was observed for nitrite-N and nitrate-N. The control tanks presented the best results ( $p<0.05)$ compared to treatments with 60 and 120 oysters, and these were similar $(p>0.05)$, except for the fifth week, when treatment with 60 oysters removed more significantly nitrite- $\mathrm{N}$ and nitrate- $\mathrm{N}$ in the effluent than in the treatment with 120 oysters.

Every week there was a greater reduction $(p<0.05)$ in levels of orthophosphate-P in the treatment of effluent control in the treatments containing oysters and, between them, there was no significant difference.

In relation to the suspended solids, the treatments containing oysters, regardless of density, were higher

Figure 2 - Weekly variation of physical and chemical variables of the effluent entering the experimental system
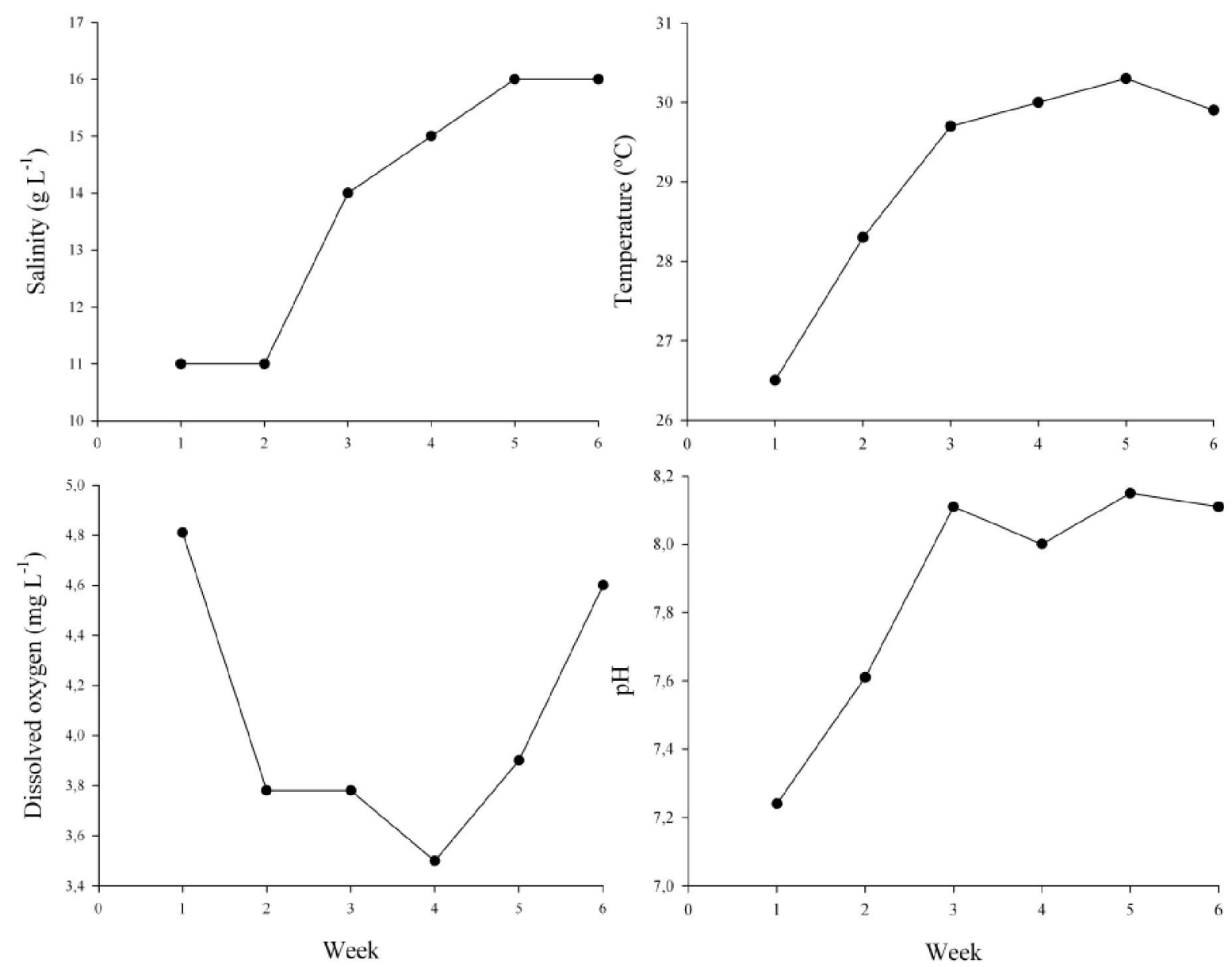
$(p<0.05)$ in removal to control. In the last two weeks, treatment with 120 oysters was higher $(p<0.05)$ to treatment with 60 oysters.
The treatments with oysters removal chlorophyll- $a$ content similarly $(p>0.05)$ and these were higher $(p<0.05)$ than control.

Figure 3 - Weekly variation of nutrients from the effluent entering and after passing through the experimental tanks
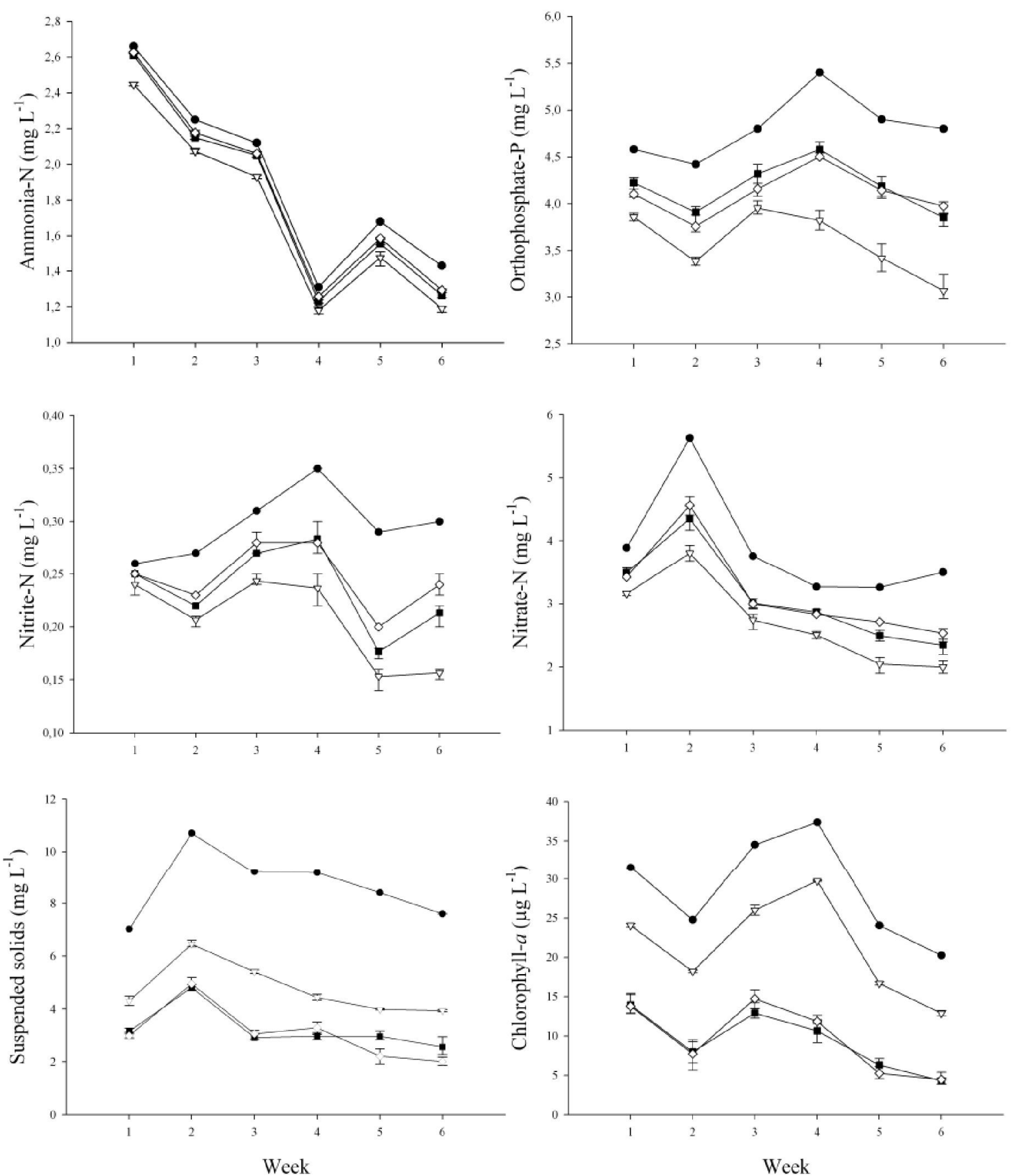

- Entering

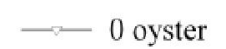

- 60 oysters

120 oysters 
Figure 4 - Percentage of weekly nutrient removal according to the treatment. Vertical bars represent mean \pm standard deviation $(\mathrm{n}=6)$. Means followed by different letters within bars for each nutrient differ by Tukey's HSD test $(P<0.05)$
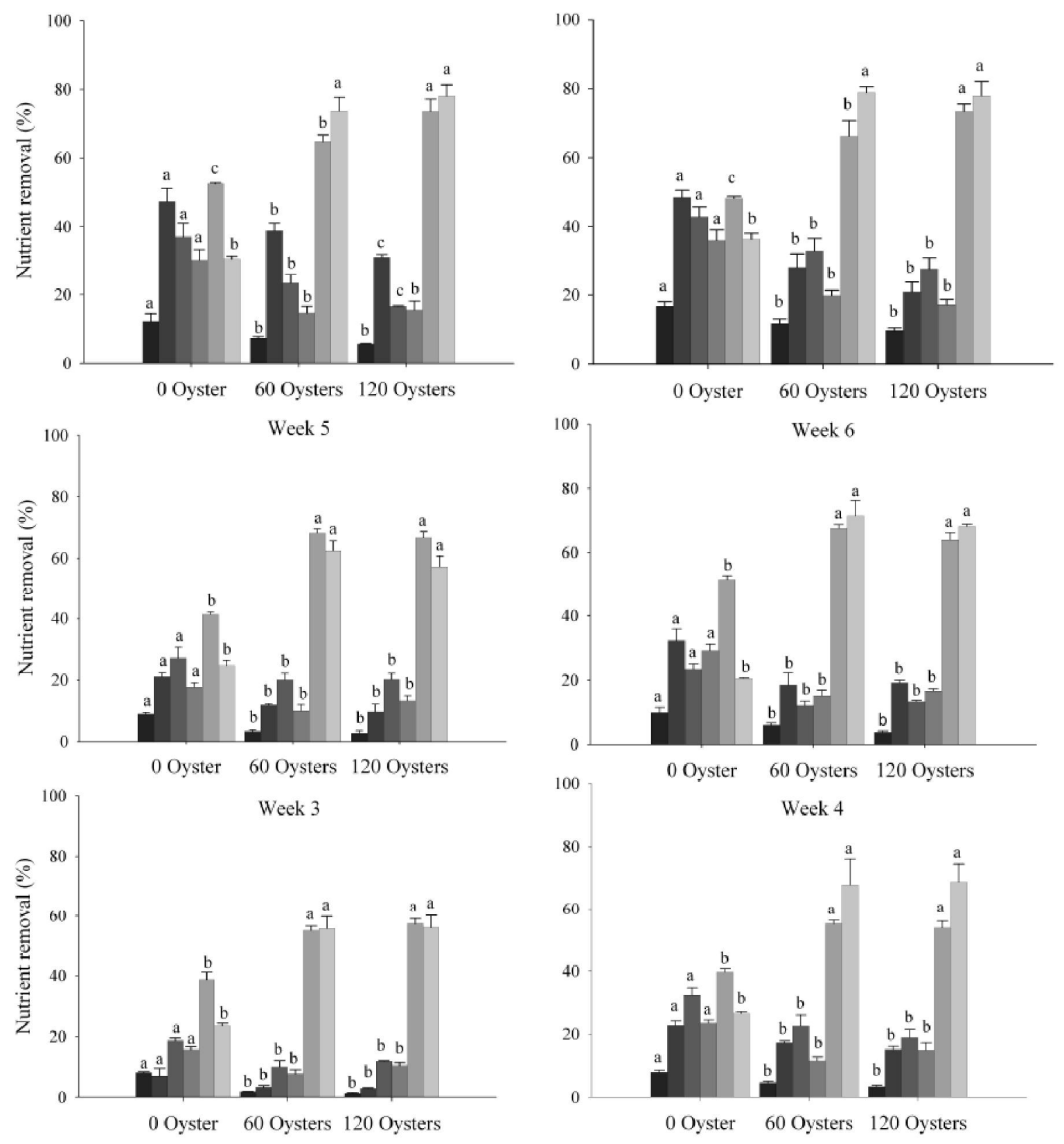

Week 1

Week 2

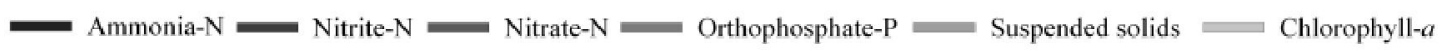

Júnior et al. (2005) and Ramos et al. (2010), using oyster $C$. rhizophorae in the treatment of effluents from fish and shrimp farming, respectively, observed reduction in levels of nitrogen compounds in the water after passage through the oysters. Regarding the removal of nitrogen compounds, contrary results 
were obtained by Jones, Dennison and Perston (2001) and Ramos, Vinatea and Costa (2008), using oysters Saccostrea commercialis and C. rhizophorae, respectively, in treatment of shrimp farm effluents.

Even the treatments with oyster were less efficient than control treatment, the removal of ammonia-N becomes an important aspect in this study inasmuch as most aquatic organisms release ammonia-N as nitrogen excreta (RUPPERT; BARNES, 2005). Jones, Dennison and Perston (2001), in experiment with $S$. commercialis, observed release rate of $0.52 \mu \mathrm{mol} \mathrm{h}^{-1}$. Júnior et al. (2005) suggested that the reduction in levels of ammonia-N, after passing by oysters may be due to elevated sequestration of suspended organic matter, making it unavailable for the generation of ammonia-N.

In this experiment, it was possible to observe the formation of biofilm on the walls of all the experimental ponds. Paniagua-Michel and Garcia (2003), working with substrates for biofilm growth in the treatment of effluents from shrimp farming, found ammonia$\mathrm{N}$ removal efficiency of 97\%. Burford et al. (2003) indicated that nitrifying bacteria present in biofilms have an important role in controlling water quality through nutrient cycling, converting ammonia- $\mathrm{N}$ into nitrite- $\mathrm{N}$ and this one into nitrate- $\mathrm{N}$ via nitrification. Thus, it can be inferred that the reduction in the concentration of ammonia- $\mathrm{N}$ may have been due to the transformation of nitrite- $\mathrm{N}$ through nitrification process.

Júnior et al. (2005) observed reduction in levels of nitrite- $\mathrm{N}$ and nitrate- $\mathrm{N}$ in sedimentation tanks of 99.6 and $55.9 \%$, respectively, attributing this reduction to a complete settlement of the bacterial community in sedimentation tank after two weeks. The same situation may have occurred in this experiment inasmuch as there was a tendency for greater removal of nitrite-N and nitrate-N, over the weeks (Figure 4).

Moreover, the presence of microalgae and cyanobacteria in biofilms can reduce the concentration of nitrogen compounds by absorption (RICHOUX; THOMPSON, 2001). With respect to orthophosphate-P, Ramos et al. (2010), using the integrated sedimentation system, oysters (C. rhizophorae) and macroalgae, obtained removal of 15.0 and $6.5 \%$, respectively, by processes of sedimentation and filtration by oysters. Júnior et al. (2005) observed $56.1 \%$ reduction in the concentration of orthophosphate-P after the filtration process by oysters $C$. rhizophorae. According to Ebeling, Timmons and Bisogni (2006), heterotrophic bacteria can convert nitrogen and phosphorus into bacterial biomass. One possible explanation for the greatest reductions in orthophosphate-P in control tanks compared to tanks with oysters, is its capture by sediment bacteria inasmuch as in these tanks, the number of bacteria tends to be higher for Jones, Dennison and Perston (2001) and Ramos et al. (2010), during the filtration phase by oysters S. commercialis and C. rhizophorae, respectively, observed removal for total bacteria of 70 and $95 \%$, respectively.

The removal of suspended solids has been found effective by the processes of sedimentation and also by filtration through the use of bivalves (JONES; DENNISON; PERSTON, 2001; JONES; PERSTON; DENNISON, 2002). Ramos, Vinatea and Costa (2008) observed greater values of suspended solids removal for the process of filtration by oysters $(69.4 \%)$ compared to the sedimentation process $(35.7 \%)$.

In relation to the chlorophyll- $a$, Ramos, Vinatea and Costa (2008) obtained as result, $45.4 \%$ of removal by sedimentation process, and $100 \%$ through filtration by oysters. Better efficiency was obtained by Ramos et al. (2010), reaching in their studies $90 \%$ by sedimentation process and $100 \%$ by oysters filtration. Jones, Dennison and Perston (2001) found $72 \%$ efficiency in the removal of chlorophyll- $a$ through the filtration by oysters. Early study have demonstrated the effectiveness of bivalve molluscs in reducing the phytoplankton in the water column (DAME, 1993). According to Jones, Perston and Dennison (2002), oysters remove large amounts of phytoplankton, bacteria and suspended solids in the water column by selecting the particles by size, weight and composition, preferably consuming organic matter in detriment to inorganic matter, which explains the higher removal efficiency in chlorophyll- $a$ during the entire experiment.

Compared to data obtained by other studies, the results can be considered satisfactory, inasmuch as even subject to climate variations, water quality, nutrient input, which affect the rate of sedimentation and filtration by oysters, there was nutrient removal every week, even with greater efficiency for suspended solids and chlorophyll- $a$, obtaining for these parameters, removal over $50 \%$ every week, in treatments with oysters.

The stocking density of oysters affected $(p<0.05)$ the daily growth rate in height. The same pattern was not observed in width, in which, regardless of stocking density, oysters showed a similar growth pattern $(p>0.05)$ (Table 1).

In relation to wet weight and dry weight, difference was observed $(p<0.05)$ among oysters at the beginning and end of the experiment. Stocking density did not affect $(p>0.05)$ these variables as well as daily weight gain (Table 2).

Oysters grown in lower density grew, in relation to height, $15 \%$ more than those grown at higher density 
Table 1 - Biometry (mean \pm SD) of Crassostrea rhizophorae at the end of six weeks according to the treatment

\begin{tabular}{|c|c|c|c|c|}
\hline \multirow{2}{*}{ Parameter } & \multicolumn{2}{|c|}{ Treatment } & \multirow{2}{*}{$\mathrm{F}$} & \multirow{2}{*}{$\mathrm{P}$} \\
\hline & 60 oysters & 120 oysters & & \\
\hline \multicolumn{5}{|l|}{ Height } \\
\hline Initial (mm) & $46.57 \pm 3.40$ & $46.04 \pm 3.89$ & & \\
\hline Final (mm) & $54.76 \pm 2.77$ & $53.18 \pm 2.77$ & 4.55 & 0.1321 \\
\hline Daily growth rate $\left(\mathrm{mm} \mathrm{day}^{-1}\right)$ & $0.20 \pm 0.02 \mathrm{a}$ & $0.17 \pm 0.02 b$ & 35.74 & 0.0012 \\
\hline \multicolumn{5}{|l|}{ Width } \\
\hline Initial (mm) & $16.63 \pm 3.54$ & $16.81 \pm 3.37$ & & \\
\hline Final (mm) & $20.81 \pm 1.18$ & $20.91 \pm 1.86$ & 2.88 & 0.3573 \\
\hline Daily growth rate $\left(\mathrm{mm}\right.$ day $\left.^{-1}\right)$ & $0.09 \pm 0.01 \mathrm{a}$ & $0.10 \pm 0.01 \mathrm{a}$ & 22.76 & 0.0154 \\
\hline
\end{tabular}

Means within lines followed by different letters differ significantly by Tukey's HSD test at $5 \%$ of probability

Table 2 - Weight $($ mean $\pm \mathrm{SD})(\mathrm{n}=10)$ initial and at the end of six weeks of Crassostrea rhizophorae according to the treatment

\begin{tabular}{|c|c|c|c|c|c|}
\hline \multirow{2}{*}{ Parameter } & \multirow{2}{*}{ Initial } & \multicolumn{2}{|c|}{ Treatment } & \multirow{2}{*}{$\mathrm{F}$} & \multirow{2}{*}{$\mathrm{P}$} \\
\hline & & 60 oysters & 120 oysters & & \\
\hline Wet weight $(\mathrm{g})$ & $3.62 \pm 0.30 b$ & $4.77 \pm 0.18 \mathrm{a}$ & $4.24 \pm 0.16 \mathrm{a}$ & 23.74 & 0.0214 \\
\hline Dry weight (g) & $0.40 \pm 0.07 b$ & $0.65 \pm 0.03 \mathrm{a}$ & $0.59 \pm 0.03 \mathrm{a}$ & 34.41 & 0.0051 \\
\hline Wet weight gain (mg day $\left.{ }^{-1}\right)$ & - & $85.24 \pm 3.22 \mathrm{a}$ & $75.77 \pm 2.86 \mathrm{a}$ & 2.77 & 0.7415 \\
\hline Dry weight (mg day ${ }^{-1}$ ) & - & $11.61 \pm 0.54 \mathrm{a}$ & $10.48 \pm 0.45 \mathrm{a}$ & 2.76 & 0.8361 \\
\hline
\end{tabular}

Means within lines followed by different letters statically differ by Tukey's HSD test at $5 \%$ of probability

(Table 1). In general, as noted by some authors, the differences found for oyster growth can be explained by weather conditions, water quality, cultivation systems and management of culture structures, species used and genetics of the oysters (HERNÁNDEZ; TROCCOLI; MILLIÁN, 1998; PEREIRA et al., 2001).

The growth in higher densities may be limited by reduced feed availability when compared to lower densities and the physical contact by space limitation (HADLEY; MANZI, 1984; HONKOOP; BAYNE, 2002; TAYLOR et al., 1997).

According to Soniat et al. (1998), chlorophyll$a$ can provide a basis for estimating the supply of feed for oysters. Thus, it can be stated that during the experimental period, there was great feed availability for the oysters, ranging from 20.25 to $37.38 \mu \mathrm{g} \mathrm{L}^{-1}$ over the weeks (Figure 3). However, according to Holliday, Maguire and Nell (1991) and Taylor et al. (1997), even with feed abundance, feed intake and reduced growth by oysters can be inhibited by contact between neighboring individuals, and it may even cause damage to the valves inasmuch as when there is damage, energy will be used for repair. Also according to Honkoop and
Bayne (2002) and Maccacchero, Guzenski and Ferreira (2005), the contact among individuals can affect the shape of the valves, reducing the acceptance and market value.

By comparing to initial body weight, it is observed that the wet weight increased by 24.11 and $14.62 \%$ for 60 and 120 oysters, respectively, and dry weight increased by 38.46 and $32.20 \%$ for 60 and 120 oysters, respectively at the end of the experiment (Table 2). Hernández, Troccoli and Millián (1998) observed for C. rhizophorae the same pattern in the weight obtained in this experiment, with an increase of wet and dry weight as the growth in height was increased. Based on the results obtained for weight (wet and dry), it can be inferred that the available feed was sufficient for similar growth in weight at different densities inasmuch as in low feed availability cultivation areas, bivalves invest energy in growth of the valves at the expense of somatic growth (FRANZ, 1993; HADLEY; MANZI, 1984). Also, according to Franz (1993), guild grown in a low feed availability environment adapted by developing their gills more, which have their size positively correlated to filtration rate. According to Shpigel et al. (1993), the great performance of oysters cultivated with effluents is due to the high diversity of algae and constant feed concentration. 
For condition index and yield, difference was observed $(p<0.05)$ among oysters at the beginning and end of the experiment, but among tested densities, there was no significant difference $(p>0.05)$ (Table 3).

It can be observed that the condition index of oysters increased by 50.61 and $48.78 \%$, for density of 60 and 120 oysters, respectively, in comparison to the start of the experiment. Similarly, the yield of oysters improved by 14.78 and $11.79 \%$ for density of 60 and 120 oysters, respectively (Table 3 ). According to Lucas and Beninger (1985), the higher these parameters are, the greater the representation of the weight of soft tissues in relation to total weight. However, these indices appear to be strongly related to the reproductive period, because according to Galvão et al. (2000), higher values of condition index in oysters at the stage of maturation are found in this phase especially due to higher glycogen accumulation. Moreover, Quayle and Newkirk (1989) indicated that a higher value of condition index suggests that the oyster is well fed. The relationship between condition index and nutritional status was also cited by Ren, Ross and Schiel (2003) for C. virginica and Orban et al. (2004) for C. gigas.

There was no statistical difference $(p>0.05)$ between treatments with 60 and 120 oysters for the parameters of body composition, obtaining, in average, 86.26; 4.66; 2.03 and $1.80 \%$ for moisture, crude protein, ether extract and ash, respectively. In relation to the initial body composition in ether extract, oysters after six weeks of cultivation presented values 20.59 and $19.40 \%$ higher $(p<0.05)$ for treatments with 60 and 120 oysters, respectively. For the other fractions, there was no significant difference among treatments (Table 4).

For body composition, in natural populations of oysters $C$. rhizophorae in mangroves along the Brazilian coast, Pedroza and Cozzolino (2001) and Martino and Cruz (2004) found lower values for moisture ( 80 to $82 \%$ ), higher values for crude protein (9.7 to $14 \%$ ) and similar values for ether extract (1.7 to $2.0 \%$ ) and mineral matter (1.4 to $3.1 \%)$. The variation between the body composition of oysters are due to the season, cultivation or capture local, age, sex, size, feed availability and reproductive cycle (PIGOT; TUCKER, 1990). In this experiment, different cultivation areas and feed availability (because the oysters used in this experiment were from other cultivation) may have been responsible for the variation between the initial and final body composition for the ether extract fraction.

For survival rate, there was no difference $(p>0.05)$ among treatments (Figure 5).

Corroborating these results, some authors found no positive relationship between mortality and stocking density (CHÁVEZ-VILLALBA; ARREOLA-LIZÁRRA; BURROLA-SANCHEZ, 2010; HONKOOP; BAYNE, 2002) for C. gigas. However, Jones, Perston and Dennison

Table 3 - Index of condition and initial and final yield (mean \pm SD) $(n=10)$ of Crassostrea rhizophorae at the end of six weeks according to the treatment

\begin{tabular}{lccccc}
\hline \multirow{2}{*}{ Parameter } & \multirow{2}{*}{ Initial } & \multicolumn{2}{c}{ Treatment } & F & P \\
\cline { 2 - 6 } & & 60 oysters & 120 oysters & \\
\hline Condition index $(\%)$ & $1.64 \pm 0.52 \mathrm{~b}$ & $2.47 \pm 0.27 \mathrm{a}$ & $2.44 \pm 0.28 \mathrm{a}$ & 13.67 & 0.0325 \\
Yield $(\%)$ & $17.73 \pm 2.05 \mathrm{~b}$ & $20.35 \pm 2.15 \mathrm{a}$ & $19.82 \pm 2.35 \mathrm{a}$ & 14.88 & 0.0412 \\
\hline
\end{tabular}

Means within lines followed by different letters statistically differ by Tukey's HSD test at $5 \%$ of probability

Table 4 - Initial and final body composition (mean \pm SD) $(n=5)$ of Crassostrea rhizophorae at the end of six weeks according to the treatment

\begin{tabular}{|c|c|c|c|c|c|}
\hline \multirow{2}{*}{ Parameter $^{1}$} & \multirow{2}{*}{ Initial } & \multicolumn{2}{|c|}{ Treatment } & \multirow{2}{*}{$\mathrm{F}$} & \multirow{2}{*}{$\mathrm{P}$} \\
\hline & & 60 oysters & 120 oysters & & \\
\hline Moisture (\%) & $88.95 \pm 1.40 \mathrm{a}$ & $86.38 \pm 0.13 a$ & $86.18 \pm 0.60 \mathrm{a}$ & 3.06 & 0.9856 \\
\hline Crude protein $(\%)$ & $4.57 \pm 0.40 \mathrm{a}$ & $4.79 \pm 0.22 \mathrm{a}$ & $4.53 \pm 0.19 \mathrm{a}$ & 4.21 & 0.8512 \\
\hline Ether extract (\%) & $1.62 \pm 0.09 \mathrm{~b}$ & $2.04 \pm 0.20 \mathrm{a}$ & $2.01 \pm 0.14 \mathrm{a}$ & 12.63 & 0.0415 \\
\hline Mineral matter $(\%)$ & $1.65 \pm 0.13 \mathrm{a}$ & $1.84 \pm 0.03 \mathrm{a}$ & $1.76 \pm 0.10 \mathrm{a}$ & 2.56 & 0.8456 \\
\hline
\end{tabular}

Means within lines followed by different letters statistically differ by Tukey's HSD test at $5 \%$ of probability ${ }^{1}$ On natural matter basis 
Figure 5 - Survival of Crassostrea rhizophorae after six weeks of experiment according to the treatment

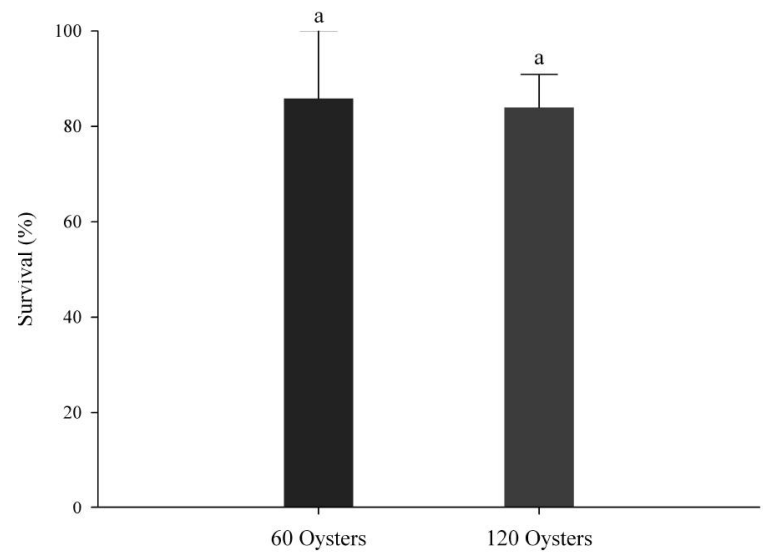

(2002), using the oyster S. commercialis as biofilters to improve the quality of effluent from shrimp farming, found higher mortality in treatment with high density.

\section{CONCLUSIONS}

1. The results of this study demonstrate the ability of the oyster Crassostrea rhizophorae in reducing nutrient concentrations in the water column, particularly the suspended solids and chlorophyll- $a$;

2. In addition to improving the quality of effluents, oysters used the nutrients for growth, showing good growth and survival indices similar to those obtained in traditional crops.

\section{ACKNOWLEDGMENTS}

The authors would like to express their sincere thanks to National Council for Scientific and Technological Development - 551837/2009-8 (CNPq), Bahia Research Foundation - 022/2008 (FAPESB) and Coordination for the Improvement of Higher Education Personnel - PROCAD-NF 2343/2008 (CAPES) for the financing of the research project.

\section{REFERENCES}

BURFORD, M. A. et al. Nutrient and microbial dynamics in high-intensity, zero-exchange shrimp ponds in Belize. Aquaculture, v. 219, n. 1/4, p. 393-411, 2003.

CAMARGO, S. G. O.; POUEY, J. L. O. F. Aquaculture - an expanding market. Revista Brasileira de Agrociência, v. 11, n. 4, p. 393-396, 2005.
CHÁVEZ-VILLALBA， J.; ARREOLA-LIZÁRRA, A.; BURROLA-SANCHEZ, S. Growth, condition, and survival of the Pacific oyster Crassostrea gigas cultivated within and outside a subtropical lagoon. Aquaculture, v. 300, n. 1/4, p. 128-136, 2010.

DAME, R. F. Bivalve Filter Feeders in Estuarine and Coastal Ecosystem Processes. Berlin, Germany: SpringerVerlag, 1993. 376 p.

DETMANN, E. et al. Métodos para análise de alimentos. Visconde do Rio Branco, MG: Suprema, 2012. 214 p.

EBELING, J. M.; TIMMONS, M. B.; BISOGNI, J. J. Engineering analysis of the stoichiometry of photoautotrophic, autotrophic, and heterotrophic removal of ammonia-nitrogen in aquaculture systems. Aquaculture, v. 257, n. 1/4, p. 346-358, 2006.

FOOD AND AGRICULTURE ORGANIZATION OF THE UNITED NATIONS. The state of World fisheries and aquaculture 2008. Rome: FAO, 2009. 164 p.

FRANZ, D. R. Allometry of shell and body weight in relation to shore level in the intertidal bivalve Geukensia demissa (Bivalvia: Mytilidae). Journal of Experimental Marine Biology and Ecology, v. 174, n. 2, p. 193-207, 1993.

GALVÃO, M. S. N. et al. Reproductive characters of the oyster Crassostrea rhizophorae from mangroves of Cananéia estuary, São Paulo, Brazil $\left(25^{\circ} \mathrm{S} ; 48^{\circ} \mathrm{W}\right)$. Boletim do Instituto de Pesca, v. 26, n. 2, p. 147-162, 2000.

GUIMARÃES, I. M. et al. Salinity influence on the survival of mangrove oyster Crassostrea rhizophorae. Arquivo de Ciência do Mar, v. 41, n. 1, p. 118-122, 2008.

HADLEY, N. H.; MANZI, J. J. Growth of seed clams, Mercenaria mercenaria, at various densities in a commercial scale nursery system. Aquaculture, v. 36, n. 4, p. 369-378, 1984.

HERNÁNDEZ, O. D.; TROCCOLI, L. G.; MILLIÁN, Y. J. Q. Crecimiento, engorde y sobrevivencia de la ostra de mangle Crassostrea rhizophorae Guilding, 1928 em la Isla de Cubagua, Venezuela. Caribbean Journal of Science, v. 34, n. 3/4, p. 243-249, 1998.

HOLliDAY, J. E.; MAGUIRE, G. B.; NELL, J. A. Optimum stocking density for nursery culture of Sydney rock oysters (Saccostrea commercialis). Aquaculture, v. 96, n. 1, p. 7-16, 1991.

HONKOOP, P. J. C.; BAYNE, B. L. Stocking density and growth of the Pacific oyster (Crassostrea gigas) and the Sydney rock oyster (Saccostrea glomerata) in Port Stephens, Australia. Aquaculture, v. 213, n. 1/4, p. 171-186, 2002.

JACKSON, C. J. et al. Managing the development of sustainable shrimp farming in Australian: the role of sedimentation ponds in treatment of farm discharge water. Aquaculture, v. 226, n. 1/4, p. 23-34, 2003.

JEFFREY, S. W.; HUMPHREY, G. F. New spectrophotometric equation for determining chlorophyll a, b, c1 and c2, Biochemistry Physiology Pflanzen, v. 167, n. 1, p. 194-204, 1975 . 
JIANG, S. Aquaculture, capture fisheries, and wild fish stocks. Resource and Energy Economics, v. 32, n. 1, p. 6577, 2010.

JONES, A. B.; DENNISON, W. C.; PERSTON, N. P. Integrated treatment of shrimp effluent by sedimentation, oyster filtration and macroalgal absorption: a laboratory scale study. Aquaculture, v. 193, n. 1/2, p. 155-178, 2001.

JONES, A. B.; PERSTON, N. P.; DENNISON, W. C. The efficiency and condition of oysters and macroalgae used as biological filters of shrimp pond effluent. Aquaculture Research, v. 33, n. 1, p. 1-19, 2002.

CAVALCANTE JÚNIOR, C. V. et al. Water reuse in an integrated system with fishes, sedimentation, oyster and macroalgae. Revista Brasileira de Engenharia Agrícola e Ambiental, v. 9 (suplemento) p. 118-122, 2005. Suplemento.

LEFEBVRE, S.; BARILLÉ, 1.; CLERC, M. Pacific oyster (Crassostrea gigas) feeding responses to a fish-farm effluent. Aquaculture, v. 187, n. 1/2, p. 185-198, 2000.

LUCAS, A.; BENINGER, P. G. The use of physiological condition indices in marine bivalve aquaculture, Aquaculture, v. 44 , n. 3 , p. $187-200,1985$.

MACCACCHERO, G. B.; GUZENSKI, J.; FERREIRA, J. F. Allometric growth on mangrove oyster Crassostrea rhizophorae (Guilding, 1828), cultured in Southern Brazil. Revista Ciência Agronômica, v. 36, n. 3, p. 400-403, 2005.

MADRIGAL, E. et al. Tasa de filtración del ostión de manglar (Crassostrea rhizophorae) Guilding, 1828, a diferentes salinidades y temperatura. Revista de Biologia Tropical, v. 33, n. 1, p. 77-79, 1985.

MARTINO, R. C.; CRUZ, G. M. Proximate composition and fatty acid content of the mangrove oyster Crassostrea rhizophorae along the year seasons. Brazilian Archives of Biology and Technology, v. 47, n. 6, p. 955-960, 2004.

MINISTÉRIODAPESCAEAQUICULTURA. Boletim estatístico da pesca e aquicultura 2010. Brasília: MPA, 2012. 129 p.

ORBAN, E. et al. Growth, nutricional quality and safety of oysters (Crassostrea gigas) cultured in the Lagoon of Venice (Italy). Journal of Science of Food and Agriculture, v. 84, n. 14, p. 1929-1938, 2004.

PANIAGUA-MICHEL, J.; GARCIA, O. Ex-situ bioremediation of shrimp culture effluent using constructed microbial mats. Aquacultural Engineering, v. 28, n. 3/4, p. 131-139, 2003.

PEDROZA, L. F. C.; COZZOLINO, S. M. F. Centesimal and mineral composition of the raw and cooked shellfishes of the Natal-RN city. Ciência e Tecnologia de Alimentos, v. 21, n. 2, p. 154-157, 2001.
PEREIRA, O. M. et al. Growth of the oyster Crassostrea brasiliana sowed on artificial beds under different densities in the estuarine lagoon of Cananéia, São Paulo, Brazil $\left(25^{\circ}\right.$ S, $\left.48^{\circ} \mathrm{W}\right)$. Boletim do Instituto de Pesca, v. 27, n. 1, p. 85-95, 2001.

PIGOTT, G. M.; TUCKER, B. W. Seafood: effects of technology on nutrition. New York: CRC Press, 1990. 384 p.

QUAYLE, D. B.; NEWKIRK, G. F. Farming bivalve molluses: methods for study and development. World Aquaculture Society, Baton Rouge, LA, USA, 1989. 294 p.

RAMOS, R.; VINATEA, L.; COSTA, R. Treatment of Litopenaeus vannamei_farming effluents by sedimentation and oyster Crassostrea rhizophorae filtration. Latin American Journal of Aquatic Research, v. 36, n. 2, p. 235-244, 2008.

RAMOS, R. et al. Treatments of effluents from Litopenaeus vannamei shrimp cultures through sedimentation, filtration and absorption. Latin American Journal of Aquatic Research, v. 38, n. 2, p. 188-200, 2010.

REN, J. S.; ROSS, A. H.; SCHIEL, D. R. Functional descriptions of feeding and energetics of the Pacific oyster Crassotrea gigas in New Zealand. Marine Ecology Progress Series, v. 208, n. 1, p. 119-130, 2003.

REYES, L. M. A. Fundamentos de acuicultura marina. Santafé de Bogotá: INPA, 1995. 225 p.

RICHOUX, N. B.; THOMPSON, R. J. Regulation of particle transport within the ventral groove of the mussel (Mytilus edulis) gill in response to environmental conditions. Journal of Experimental Marine Biology and Ecology, v. 260, n. 2, p. 199-215, 2001.

ROCHA, I. P. Carcinicultura brasileira: Processos tecnológicos, impactos sócio-econômicos, sustentabilidade ambiental, entraves e oportunidades. Revista da ABCC, v. 13, n. 1, p. 13-23, 2011.

RUPPERT, E. E.; BARNES, D. R. Zoologia dos Invertebrados. 7. ed. São Paulo: Rocca, 2005. 1168 p.

SHPIGEL, M. et al. A proposed model for "environmentally clean" land-based culture of fish, bivalves and seaweeds. Aquaculture, v. 117, n. 1/2, p. 115-128, 1993.

SONIAT, T. M. et al. Understanding the success and failure of oyster populations: the importance of sampled variables and sample timing. Journal of Shellfish Research, v. 17, n. 4/5, p. $1149-1165,1998$

TAYLOR, J. J. et al. Effects of stocking density on growth and survival of early juvenile silver-lip pearl oysters, Pinctada maxima (Jameson), held in suspended nursery culture. Aquaculture, v. 153, n. 1/2, p. 41-49, 1997. 